\title{
患者配置の最適化と看護動線量シミュレーションによる 病院病棟部における施設の計画と運営の評価に関する BIM 研究 BIM STUDY ON EVALUATION FOR HOSPITAL WARD FACILITY PLANNING AND MANAGEMENT BY OPTIMIZATION OF PATIENT PLACEMENT AND SIMULATION OF NURSING TRAVEL DISTANCE
}

\author{
加藤 彰 一 ${ }^{* 1}$, 山口恭平 ${ }^{* 2}$, 高木 碧*3, 鷲 尾佳 吾*4 \\ Akikazu KATO, Kyohei YAMAGUCHI, Midori TAKAGI \\ and Keigo WASHIO
}

\begin{abstract}
This study aims to develop the Building Information Modeling, BIM, system that enables effective facility planning, programming, design, and management of hospital wards. A circular corridor floor plan type was focused and management types regarding patient placement and nursing travel distance were considered. The nursing travel survey was conducted in four wards of two hospitals. Simulations were carried out to show optimal and inappropriate versions of patient placements using genetic algorithm. Various fit between the floor plan type and management type were clarified including the difference of nursing travel distances was small in the circular corridor floor plan type.
\end{abstract}

Keywords: Hospital Ward, Nursing Activities, Nursing Travel Distance, Building Information Modeling, Simulation, Genetic Algorithm 病院病棟部, 看護業務, 看護動線量, BIM, シミュレーション, 遺伝的アルゴリズム

\section{1. 研究の概要}

\section{1-1 研究の背景と目的}

病棟の看護動線及び看護業務の調查は多くの研究者が行い,看護 動線短縮から看護業務効率を高め,直接看護時間を増大させるとい う考えから,様々な分析やシミュレーションが行われてきた。既往研 究では,谷口ら 1)による,病棟平面モデルごとの看護動線量予測や鳥 山ら 2)による,看護拠点を変更した看護動線量予測がある。また, 欧米 では space syntax 利用の観点から看護動線研究を捉え直す研究 3)も 見られる。しかし,このようなシミュレーションは, 手動または専用 のシミュレーションソフトウェアを用いて行われてきた。

ところが近年, Building Information Modeling (BIM)及びそれと 連動する Visual Programming Language (VPL)の普及により, 建築 のデジタル情報を活用して, 計画設計段階から運営段階にいたる 様々なシミュレーションを開発・実施する環境が整った。フロント ローディングの観点から,シミュレーションを計画プロセス早期に 実施して,修正が少ない成熟した設計案の作成が可能である。

このような背景から筆者ら ${ }^{4)}$ は, BIM 上で利用可能な看護動線量 を把握するシミュレーションを開発し, 病棟の運営実態の評価・分析 を行った。ここでは最適・不適な患者の病床配置(以下, 患者配置)を 想定し,それらの患者配置における看護動線量を予測・把握すること で病棟の評価を行うことを試みている。前述の谷口ら 1)によっても
同様の試みは行われているが,これらの患者配置の変更提案は机上 の手計算で行われている。患者配置では, 渡辺ら5)により, 分散型看 護拠点を導入した病棟での中央の看護拠点と病室タイプの距離と看 護必要度の関連についての調査や,周手術期における患者の看護必 要度や病床配置についての調查が行われている。しかし, 患者配置が 看護動線に与える影響などについては言及されていない。

本研究では実際の看護動線調査を通して得られた, 実際の病棟の 患者配置を看護動線量の観点から,いくつかの条件において患者配 置を最適化するシステムを開発する。ここで得られた患者配置に変 更した際のシミュレーションを通し,病棟平面と患者配置が看護動 線量にどのような影響を与えているか,さらには効果的な計画設計 に寄与すべく,既に発表している BIM を用いた看護動線シミュレー ションとの連携の可能性を明らかにすることを目的としている。

\section{1-2 研究の方法}

本研究は以下の流れで行う。

1） 2 病院の 2 病棟,計 4 病棟における看護動線量調查から要素を抽 出, 患者配置の最適化を行う上での評価值について考察する。

2）看護動線量シミュレーションを用いて,調査時における病棟及 び看護師ごとの現状の看護動線量を把握する。

3）いくつかの条件の下,患者の配置換えを行った際の看護動線量 シミュレーションを行い,病棟施設の計画と運営の評価を行う。
三重大学大学院工学研究科建築学専攻 教授・博士 (工学) (侏) NTT ファシリティーズ東海 修士（工学）

三重大学大学院工学研究科建築学専攻博士前期課程 学士 (工学) (秼前野建築設計 学士 (工学)
Prof., Dept. of Architecture, Graduate School of Engineering, Mie Univ., Dr.Eng. NTT Facilities Tokai, Inc., M.Eng.

Grad. Student, Dept. of Architecture, Grad. Sch. of Engineering, Mie Univ., B.Eng. Maeno Architectural Design, Inc., B.Eng. 
Table 1 Outline of $\mathrm{H} \_$Hospital Wards

\begin{tabular}{|c|c|c|c|c|c|}
\hline \multirow{2}{*}{ Subject of Investigation } & \multicolumn{5}{|c|}{ H_Hospital (completed in 1988) } \\
\hline & \multicolumn{3}{|c|}{ W_Hospital Ward } & \multicolumn{2}{|c|}{ E_Hospital Ward } \\
\hline Nursing Staff System & \multicolumn{3}{|c|}{ 7:1 Patient to Nurse Ratio } & \multicolumn{2}{|c|}{ 7:1 Patient to Nurse Ratio } \\
\hline Ave. Length of Stay(day) & \multicolumn{3}{|c|}{14.8 (Dec.2018) } & \multicolumn{2}{|c|}{16.4 (Dec.2018) } \\
\hline Investigation Date & \multicolumn{3}{|c|}{ Dec. 12-13, 2018} & \multicolumn{2}{|c|}{ Dec. 05-06, 2018} \\
\hline Number of Patients / Beds & \multicolumn{3}{|c|}{$43^{*} / 50$ "2 patients in ICU } & \multicolumn{2}{|c|}{$23 / 36$} \\
\hline \begin{tabular}{|l|} 
Nursing Necessity Index \\
A: Monitoring and Treatment \\
B: Patient's Physical Conditions \\
C: Provided Medical Procedures
\end{tabular} & \multicolumn{3}{|c|}{$\begin{array}{l}A \cong 1: 26, A \cong 2: 18, A \cong 2 \text { and } B \cong 3: 12, \\
A \cong 3: 11, C \cong 1: 1, \\
A \cong 2 \text { and } B \cong 3, A \cong 3 \text { or } C \cong 1: 9\end{array}$} & \multicolumn{2}{|c|}{$\begin{array}{l}A \cong 1: 12, A \cong 2: 11, A \geqq 2 \text { and } B \cong 3: 7, \\
A=3: 6, C \cong 1: 0, \\
A \cong 2 \text { and } B \cong 3, A \cong 3 \text { or } C \cong 1: 4\end{array}$} \\
\hline Nursing System & \multicolumn{3}{|l|}{ PNS } & \multicolumn{2}{|c|}{ A.M.:PNS P.M.:Team Nursing } \\
\hline Number of Nurses & \multicolumn{3}{|l|}{18} & \multicolumn{2}{|l|}{11} \\
\hline \multirow{7}{*}{$\begin{array}{l}\text { Outlineof Nurses' Duties } \\
\text { - Subject of Investigation } \\
\text { Subject of Investigation } \\
\text { (one of two nurses) } \\
<X>\text { is the Number of } \\
\text { Nurses }\end{array}$} & \multicolumn{3}{|c|}{ OHead Nurse $<1>$} & \multicolumn{2}{|c|}{ OHead Nurse $<1>$} \\
\hline & \multirow{2}{*}{ 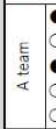 } & \multirow{2}{*}{\multicolumn{2}{|c|}{$\begin{array}{l}\text { OLeader_Day_Shift(W_D_1) }\langle 1\rangle \\
\text { ODay_Shift }\langle 1\rangle \\
\text { ODay_Long_Shift(W_DL_1) }<2> \\
\text { OEarly_Shift }<1> \\
\text { OAfternoon_Shift }\langle 1\rangle\end{array}$}} & \multirow{3}{*}{\begin{tabular}{|c|} 
A \\
Pair \\
B \\
Pair
\end{tabular}} & $\begin{array}{l}\bullet \text { Day_Shift(E_D_1) }<1> \\
\bullet \text { Day_Long_Shift(E_DL_1) }<1>\end{array}$ \\
\hline & & & & & Day_Shift(E_D_2) $<1>$ \\
\hline & & \multirow{2}{*}{\multicolumn{2}{|c|}{$\begin{array}{l}\text {-Leader_Day_Shift(W_D_2) }<1> \\
\text { ODay_Shift }<1> \\
\bullet \text { Day_Long_Shift(W_DL_2) }<2> \\
\text { OEarly_Shift }<1> \\
\text { OAfternoon_Shift }<1>\end{array}$}} & & -Day_Long_Shift(E_DL_2) $<1>$ \\
\hline & & & & $\begin{array}{c}c \\
\text { Pair } \\
\end{array}$ & $\begin{array}{l}\text { ODay_Shift }<1> \\
\text { OEarly_Shift }<1>\end{array}$ \\
\hline & Late & \multicolumn{2}{|c|}{ 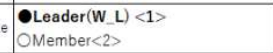 } & Late & CMember $\left(E_{-} L\right)<2>$ \\
\hline & & \multicolumn{2}{|c|}{$\begin{array}{l}\text { Leader(E_N_1 })<1> \\
\text { Member }\left(E_{-} \_ \text {N_2 }\right)<1>\end{array}$} & \multirow[t]{2}{*}{ Night } & $\begin{array}{l}\text { Leader(E_N_1)<1> } \\
\bullet \operatorname{Member}\left(E_{-} N_{2} 2\right)<1>\end{array}$ \\
\hline Investigation Time & \begin{tabular}{|l} 
Day_s \\
Day_L \\
Late_- \\
Night
\end{tabular} & $\begin{array}{l}\text { Shift } \\
\text { Lon8__Shift } \\
\text { Shift } \\
\text { t_Shigt }\end{array}$ & $\begin{array}{l}8: 30 \sim 17: 15 \\
8: 30 \sim 21: 30 \\
12: 45 \sim 21: 30 \\
20: 30 \sim 8: 30\end{array}$ & & $\begin{array}{l}8: 30 \sim 18: 30 \\
8: 30 \sim 21: 30 \\
12: 45 \sim 21: 30 \\
20: 30 \sim 8: 30\end{array}$ \\
\hline
\end{tabular}

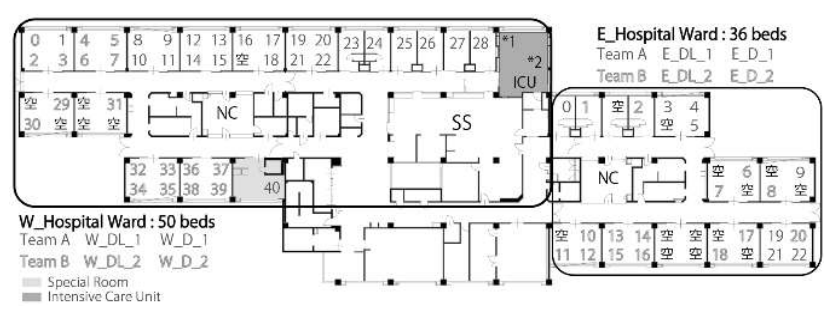

Fig. 1 Floor Plan and Patient Placement of $\mathrm{H} \_$Hospital

Table 2 Outline of G_Hospital Wards

\begin{tabular}{|c|c|c|c|c|c|}
\hline \multirow{2}{*}{ Subject of Investigation } & \multicolumn{5}{|c|}{ G_Hospital (completed in 2014) } \\
\hline & \multicolumn{3}{|c|}{ W_Hospital Ward } & \multicolumn{2}{|c|}{ E_Hospital Ward } \\
\hline Nursing Staff System & \multicolumn{3}{|c|}{ 7:1 Patient to Nurse Ratio } & \multicolumn{2}{|c|}{$7: 1$ Patient to Nurse Ratio } \\
\hline Ave. Length of Stay(day) & \multicolumn{3}{|c|}{12.8 (Jul.2019) } & \multicolumn{2}{|c|}{12.8 (Jul.2019) } \\
\hline Investigation Date & \multicolumn{3}{|c|}{ Jul. 26, 2019} & \multicolumn{2}{|c|}{ Jul. 29, 2019} \\
\hline Number of Patients / Beds & \multicolumn{3}{|c|}{$30 / 38$} & \multicolumn{2}{|c|}{$26 / 38$} \\
\hline $\begin{array}{l}\text { Nursing Necessity Index } \\
\text { A: Monitoring and Treatment } \\
\text { B: Patient's Physical Conditions } \\
\text { C: Provided Medical Procedures }\end{array}$ & \multicolumn{3}{|c|}{$\begin{array}{l}A \cong 1: 18, A \cong 2: 10, A \cong 2 \text { and } B \cong 3: 8, \\
A \cong 3: 5, C \geqq 1: 3, \\
A \geqq 2 \text { and } B \geqq 3, A \cong 3 \text { or } C \cong 1: 3\end{array}$} & \multicolumn{2}{|c|}{$\begin{array}{l}A \cong 1: 17, A \cong 2: 12, A \cong 2 \text { and } B \cong 3: 8, \\
A \cong 3: 4, C \cong 1: 0, \\
A \cong 2 \text { and } B \cong 3, A \cong 3 \text { or } C \cong 1: 0\end{array}$} \\
\hline Nursing System & \multicolumn{3}{|l|}{ PNS } & \multicolumn{2}{|l|}{ PNS } \\
\hline Number of Nurses & \multicolumn{3}{|l|}{14} & \multicolumn{2}{|l|}{15} \\
\hline \multirow{7}{*}{$\begin{array}{l}\text { Outlineof Nurses' Duties } \\
\text { : Subject of Investigation } \\
\text { : Subject of Investigation } \\
\text { (one of two nurses) } \\
<X>x \text { is the Number of } \\
\text { Nurses }\end{array}$} & \multicolumn{3}{|c|}{ OHead Nurse $<1>$} & \multicolumn{2}{|c|}{ OHead Nurse $<1>$} \\
\hline & A & Day_Shift(E_D_1) & & & $\begin{array}{l}\text { ODay_Shift }<1> \\
\text { ODay Long Shift }<1>\end{array}$ \\
\hline & \begin{tabular}{|l} 
Pair \\
B \\
Pair
\end{tabular} & $\begin{array}{l}\text { Day_Long_Shift(E_D } \\
\text { Day_Shift(E_D_2) } \\
\text { Day_Long_Shift(E_D }\end{array}$ & $\begin{array}{l}\text { DL_1) }<1> \\
<1> \\
\mathrm{DL}(2)<1>\end{array}$ & $\mid \begin{array}{c}\text { Pair } \\
\text { B } \\
\text { Pair }\end{array}$ & $\begin{array}{l}\text { ODay_Long_Shift }\langle 1\rangle \\
\text { DDay_Shift(W_D_1) }<1> \\
\text { Day_Long_Shift(W_DL_1) }\langle 1>\end{array}$ \\
\hline & $\begin{array}{c}c \\
\text { Pair } \\
\end{array}$ & $\begin{array}{l}\text { ODay_Shift }<1> \\
\text { OEarly_Shift }<1> \\
\text { ODay_Long_Shift }<1>\end{array}$ & & $\begin{array}{c}c \\
\text { Pair }\end{array}$ & $\begin{array}{l}\text { Day_Shift(W_D_1) }<1> \\
\text { OEarly_Shift }<1> \\
\text { Day_Long_Shift(W_DL_1) }<1>\end{array}$ \\
\hline & \begin{tabular}{|c|}
$D$ \\
\end{tabular} & $\begin{array}{l}\text { ODay_Shift }\langle 2> \\
\text { ODay_Long_Shift }<1>\end{array}$ & & $\begin{array}{c} \\
\text { Pair }\end{array}$ & $\begin{array}{l}\text { ODay_Shift }<2> \\
\text { ODay_Long_Shift }<1>\end{array}$ \\
\hline & 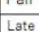 & OMember<1> & & Late & - \\
\hline & & $\begin{array}{l}\text { OLeader }<1> \\
\text { OMember }<2>\end{array}$ & & Night & $\begin{array}{l}\text { OLeader }<1> \\
\text { OMember }<3>\end{array}$ \\
\hline Investigation Time & $\begin{array}{l}\text { Day_ } \\
\text { Day_ } \\
\text { Late_ } \\
\text { Night }\end{array}$ & $\begin{array}{l}\text { Shift } \\
\text { Long_Shift } \\
\text { Shift } \\
\text { EShigt }\end{array}$ & $\begin{array}{l}8: 30 \sim 17: \\
8: 30 \sim 21: \\
12: 00 \sim 20 \\
20: 30 \sim 9:\end{array}$ & & \\
\hline
\end{tabular}

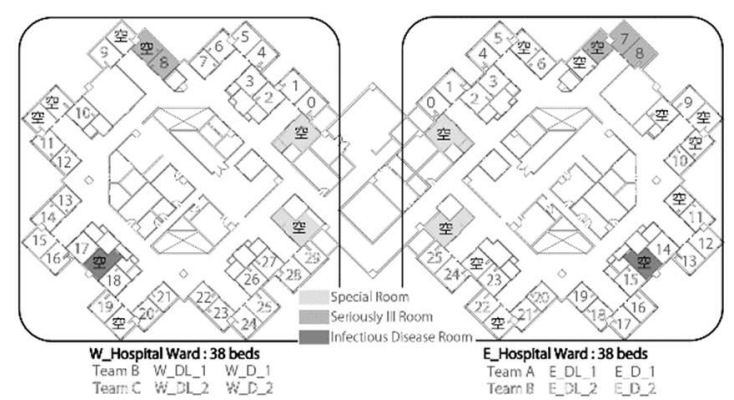

Fig. 2 Floor Plan and Patient Placement of G Hospital

\section{2. 調査の概要}

2-1 調査病棟の概要 (Table 1, Table 2)

本調查は, $\mathrm{H}$ 病院の内科系 2 病棟 $(\mathrm{W}$ 病棟, $\mathrm{E}$ 病棟)及び $\mathrm{G}$ 病院の外 科系・内科系 1 病棟ずつ $(\mathrm{W}$ 病棟, $\mathrm{E}$ 病棟 $)$ にて実施した。

(1) $\mathrm{H}$ 病院

$\mathrm{H}$ 病院は諏訪中央病院のように分散型看護拠点を持つ病棟であり, $\mathrm{E}$ 病棟がナースコーナー(以下, $\mathrm{NC}), \mathrm{W}$ 病棟が中央のスタッフステ ーション(以下,SS)を看護拠点として利用している。調查対象看護師 は,各病棟の日勤看護師, 日中看護師各 2 名である注 1)(Fig. 1)。

(2) $G$ 病院

$\mathrm{G}$ 病院は神戸市立中央市民病院の旧病棟のように病床群の中心に $\mathrm{SS}$ が位置しており, 聖路加国際病院のように全室個室病棟であると ともに,個室を多床室のように構成するユニット型個室を採用した 新しい形態をもつ病院である。中央の SS を中心に 8 つのユニット ホールを設けている(Fig. 2)。回廊型円形的病棟平面と呼称する。

\section{2-2 調査の方法}

本調査では,看護師 1 人に対し調查員 1 人が追跡するタイムスタ ディ法を行った。調查員は SS などの看護拠点内,病棟廊下,病室の扉 前までの範囲内の動きを追跡し,業務内容・時刻・地点・携帯物等を 記録する。以降本稿では, 両病院両病棟の調査対象看護師を Table.1,2 中の記号(病棟名_シフト_ナンバー)を用い表示する。

\section{3. 看護動線量・患者配置への影響因子に関する分析}

患者配置の最適化を行う上での評価值になり得る要素を,看護必 要度や看護師の病室訪問回数などから分析を行う。また, $\mathrm{H}$ 病院に

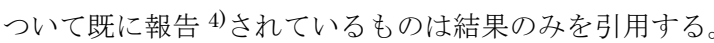

\section{3-1 病室訪問回数と看護必要度の関係性}

看護必要度注 2) とは,患者の看護のケアの度合いを示寸指標であり， 入院料の申請にも使われるため,多くの病院で使用されている。本分 析では,患者の看護必要度と病室訪問回数との関係性を分析するこ とで,患者の重症度と看護動線量の増減に関する関係性を明らかに する。渡辺ら $5^{5}$ は, 日勤看護師では看護担当患者に対する訪問回数と 看護必要度の $\mathrm{B}$ 項目にやや強い関係があると述べている。

調查日当日の各病棟における病床機能報告項目ごとの患者人数を Table 1, Table 2 に示す。

\section{3-2 患者配置と看護必要度の関係性}

ここでは患者配置,つまり看護拠点と各病室までの距離と看護必 要度の関係性について分析する。各病院のヒアリングにより $\mathrm{H}$ 病院 では，看護必要度 $\mathrm{B}$ 項目が大きい患者を,看護拠点から近い場所に 配置したことを報告した ${ }^{4)}$ 。ま $\mathrm{G}$ 病院では,看護拠点と各病室まで の距離は考慮せず,無作為に患者が配置されたことが分かった。これ により $\mathrm{G}$ 病院の病棟が $\mathrm{SS}$ から病室までの距離を重視していないこ とが把握できた。

\section{3-3環境行動面から見た看護師の動き}

文献 2)では, space syntax 利用という観点から, 環境行動研究的 仮説として「看護師は距離的により近い病室により頻繁に訪問する」 を設定してその検証を試みている。興味深い仮説設定と検証である が,上述のように看護師の動きは目的的なものであり, 業務プロセス 要因である看護必要度との関係性を重視すべきと考える。 
Table 3 Number of Visits to Patient

\begin{tabular}{|c|c|c|c|c|c|c|c|c|c|c|c|c|c|c|c|c|c|c|c|c|}
\hline \multirow{4}{*}{$\begin{array}{l}\text { Team } \\
\text { Nurse }\end{array}$} & \multicolumn{10}{|c|}{ H_Hospital } & \multicolumn{10}{|c|}{ G_Hospital } \\
\hline & \multicolumn{5}{|c|}{ W_Hospital Ward } & \multicolumn{5}{|c|}{ E_Hospital Ward } & \multicolumn{5}{|c|}{ W_Hospital Ward } & \multicolumn{5}{|c|}{ E_Hospital Ward } \\
\hline & \multicolumn{2}{|c|}{ A } & \multicolumn{2}{|c|}{ B } & \multirow{2}{*}{ Total } & \multicolumn{2}{|c|}{ A } & \multicolumn{2}{|c|}{ B } & \multirow{2}{*}{ Total } & \multicolumn{2}{|c|}{ B } & \multicolumn{2}{|c|}{$\mathrm{C}$} & \multirow{2}{*}{ Total } & \multicolumn{2}{|c|}{ A } & \multicolumn{2}{|c|}{ B } & \multirow{2}{*}{ Total } \\
\hline & w_DL_1 & W_D_1 & W_DL_2 & W_D_2 & & E_DL_1 & E_D_1 & E_DL_2 & E_D_2 & & W_DL_1 & W_D_1 & W_DL_2 & W_D_2 & & E_DL_1 & E_D_1 & E_DL_2 & E_D_2 & \\
\hline \multirow{2}{*}{$\begin{array}{l}\text { Number of Visits to } \\
\text { Patient in Charge }\end{array}$} & 123 & 73 & 105 & 42 & 343 & 81 & 43 & 127 & 61 & 312 & 75 & 33 & 36 & 23 & 167 & 50 & 32 & 102 & 32 & 216 \\
\hline & $100 \%$ & $100 \%$ & $52.2 \%$ & $61.8 \%$ & $73.8 \%$ & $60.9 \%$ & $74.1 \%$ & $88.8 \%$ & $75.3 \%$ & $75.2 \%$ & $83.3 \%$ & $91.7 \%$ & $76.6 \%$ & $82.1 \%$ & $83.1 \%$ & $68.5 \%$ & $62.7 \%$ & $84.3 \%$ & $80.7 \%$ & $75.0 \%$ \\
\hline \multirow{2}{*}{$\begin{array}{c}\text { Number of } \\
\text { Visits to Patient } \\
\text { NOT in Charge }\end{array}$} & 0 & 0 & 96 & 26 & 122 & 52 & 15 & 16 & 20 & 103 & 15 & 3 & 11 & 5 & 34 & 23 & 19 & 19 & 11 & 72 \\
\hline & $0.0 \%$ & $0.0 \%$ & $47.8 \%$ & $38.2 \%$ & $26.2 \%$ & $39.1 \%$ & $25.9 \%$ & $11.2 \%$ & $24.7 \%$ & $24.8 \%$ & $16.7 \%$ & $8.3 \%$ & $23.4 \%$ & $17.9 \%$ & $16.9 \%$ & $31.3 \%$ & $37.3 \%$ & $15.7 \%$ & $19.3 \%$ & $25.0 \%$ \\
\hline
\end{tabular}

\section{3-4 PNS の観点から見た看護師の動き}

G 病院では, Partnership Nursing System (PNS) 注 3) を全病棟 に 2018 年から導入している。E病棟の PNS ペアの E_DL_1 と E_D_1の動きのパターンを見ると, 定時の回診時には 2 人同時に動 いており，1 日の総動線量としても大きな違いはない。文献 6) と同 様に,動きの面から対等な立場を検証できたと考える。

\section{3-5 担当患者・担当外患者の訪問回数}

ここでは,対象看護師の訪問回数のうち,担当患者の看護を行う回 数と割合について分析する注 4 ) (Table 3)。

$\mathrm{H}$ 病院では全ての看護師で,担当患者への訪問回数が担当外患者 と比較して多くなっている。特に $\mathrm{W}$ 病棟 $\mathrm{A}$ チームの看護師は担当 外患者への移動が全くみられなかった。しかし, 看護師 4 名の合計で みると $\mathrm{W}$ 病棟が $73.8 \%, \mathrm{E}$ 病棟が $75.2 \%$ となり, $\mathrm{W}$ 病棟 $\mathrm{B}$ チームの 担当外患者への訪問回数が比較的多くなっている。特にW_DL_2 は $47.8 \%$ と半分に近い回数を担当外患者へ訪問している。

$\mathrm{G}$ 病院でも全ての看護師で,担当患者への訪問回数が担当外患者 と比較して多くなっている。看護師 4 名の合計をみると, $\mathrm{W}$ 病棟が $83.1 \%, \mathrm{E}$ 病棟が $75.0 \%$ となっており, $\mathrm{H}$ 病院と比較しても $\mathrm{W}$ 病棟 の担当外患者への訪問回数が少なくなっている。これは,ナースコー ルの対応や休毠者の代行, 食事の配膳などに限られ, 手が空いている, できるなら対応するという業務に係わる考え方によるものである。

\section{4. 患者配置の最適化アルゴリズムの作成}

本アルゴリズムは,病棟内において看護動線量の観点から見て必 ずしも適切であるとは限らない患者配置について,いくつかの条件 の下, 最適化された患者配置を得ることを目的としている。

アルゴリズムの作成には Python 3.7 を用い, BIM シミュレーショ ンへの適用には, BIM ソフトに Autodesk 社の Revit を使用し, Revit のVPLである Dynamo をプログラミングソフトとして使用 する。また, Dynamo 上にテキストプログラミング言語を入力する 際に IronPython2.7 及び Design Script を使用する。

\section{4-1 アルゴリズムの概要}

ここで作成する患者配置の最適化アルゴリズムでは,組合せ最適 化問題の一つである二次割当問題と最適解の探索手法の一つである 遺伝的アルゴリズム(Genetic Algorithm：以下, GA) 注5)を用い, 病 室入室条件などを考慮して,最適化を行う。

二次割当問題は人材や物資, 資金などの最適配置を見出すことを 目的とした組合せ最適化の問題である 7)。 $n$ 個の場所に $n$ 個の部門 を配置したとき,各部門が配置された場所間の物理的な距離を対象 行列 $W$ (距離行列), 各部門間のつながりの強さ(往来の多さなど)の 相互関係を対象行列 $F$ (相互関係行列) で与える。その $2 つ の$ 行列 を掛合せ,総和評価值が最小となる配置を最適解とするものである。 本アルゴリズムは, $n$ 人の患者を $n$ 個のベッドに配置する二次割当

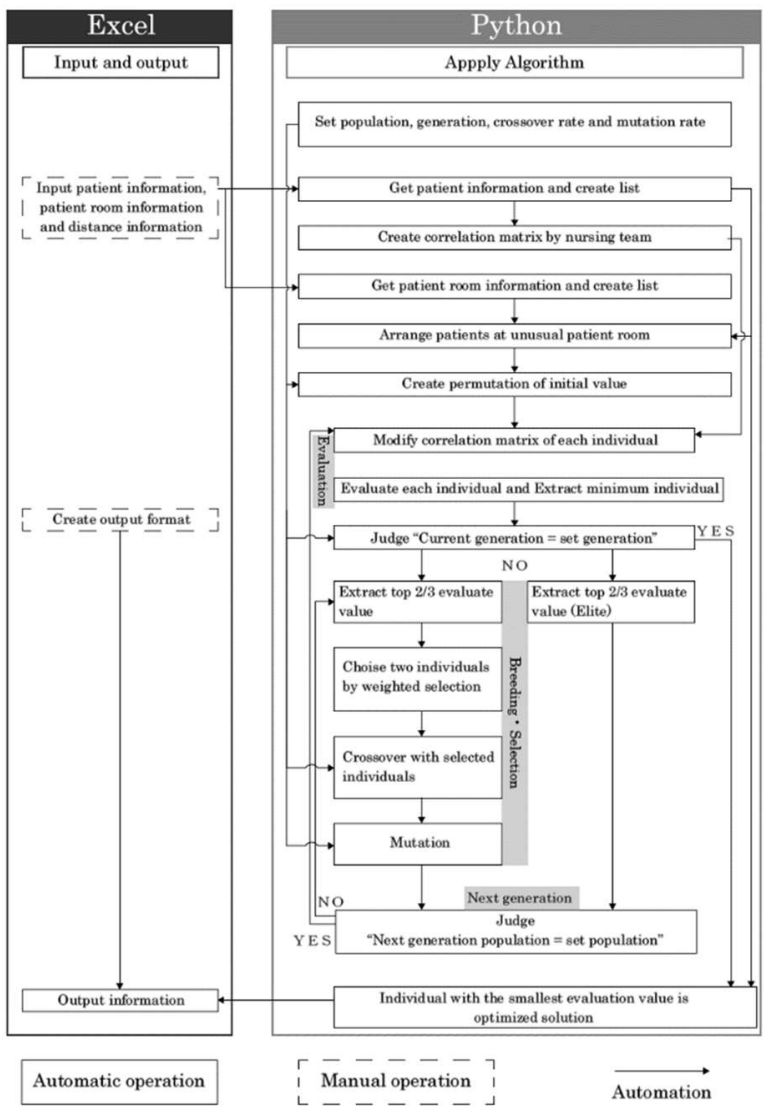

Fig. 3 System Flow

問題を GA で最適化するものとする。二次割当問題の距離行列 $W$ は 病室 (ベッド) 間の距離,相互関係行列 $F$ は看護師チームの担当患者 から移動頻度を仮定して適用する。担当患者の訪問回数が多いので, 担当患者一の移動頻度を多く,担当外への移動頻度を少なくし, 空床 への移動頻度を 0 とした。また GA 内で最適化する遺伝子は, 二次割 当問題で配置する患者の順番を順列表現とした。

患者配置を決定する際に G 病院のような全室個室の場合は同室 となる患者の条件を考える必要はないが, $\mathrm{H}$ 病院の 4 床室などに患 者配置を行う場合は男女が同じ室に入室しないようにするなど,患 者配置に制限が生まれる。本研究では, 両病院以外の病棟でも適用を 容易にするため,システムの主要な軸は変更することなく,個室・4 床 室どちらでも適用できるようにアルゴリズムを作成する。また, 普通 病室とは区別する必要のある, $\mathrm{H}$ 病院における個室病室や $\mathrm{G}$ 病院に おける重症室,感染症病室など(以下,特殊病室)から普通病室への転 床は,病床移動の実態がないものとして,その特殊病室の範囲内での 移動しか行われないように制限した。さらに, $\mathrm{H}$ 病院看護師長のヒ アリングより看護必要度 $\mathrm{B}$ 項目が大きい患者を看護拠点から近い 病室に配置すると述べていたが, $\mathrm{W}$ 病棟 $\mathrm{NC}$ の西奥(29 31)や $\mathrm{E}$ 病 棟 $\mathrm{NC}$ の右奥(6 9)(以下,端部病床)の患者配置について言及してい 
なかった。また調査日当日の端部病床は空があり, 前後 2 週間の新規 入院患者が端部病床に配置される頻度は少なかったため, 端部病床 への配置頻度について考慮せずアルゴリズムを作成する。

\section{4-2 アルゴリズムのシステムフロー}

本アルゴリズムは，以下の流れで実行される(Fig. 3)。

(1) Excelに患者情報,病室情報などを作成

最適化を行う際の評価值を求めるために,最適化を行う対象病棟 に入院する患者の情報, 特殊病室の情報, 病室間及び病室 $-\mathrm{SS}$ 間の距 離情報を Excel に入力し,管理する。

(2) 遺伝的アルゴリズムによる最適化

病棟において患者配置を行う上で,患者への移動頻度や病室間の 距離だけでなく, 看護必要度や SS-病室間の距離も考慮する必要が あることが分かった。そのため, 評価値の算出には二次割当問題の評 価值に一部変更を加え,以下の式を用いる。

$$
C(P)=\sum_{i=1}^{n} \sum_{j=1}^{n} w_{i j} f_{\pi(i) \pi(j)} D_{j} N_{\pi(j)}
$$

病室数を $n$, 距離行列を $W=[w i j](1 \leqq i, j \leqq n)$, 相互関係行列を $F=[f i j](1 \leqq i, j \leqq n), \mathrm{SS}$ 一病室間の距離を $D=[D j](j \leqq n)$, 看護必要度 を $N=[N j](j \leqq n)$ としている。GA の選択方法及び交叉方法は,ルー レット選択・順序交叉とし, 個体数 $=32$, 交叉確率 $=90 \%$, 突然変異確 率=1\%とした。世代数については病棟により収束值の違いが生まれ るため,実際のアルゴリズムの実行により収束值の検証を行い決定 した。また看護必要度が 0 である患者も存在しているが,計算を行う 上で便宜上全ての患者に 1 を加え, 1 以上としている。

(3) Excelに最適化された患者配置を出力

Excel 上に最適化された患者配置を出力する。看護師の一般の業 務での利用も容易にするため, Excel 上に情報を入出力している。

\section{4-3 BIM シミュレーションへの適用}

最適化アルゴリズムを設計段階で利用する際は,筆者らが開発し た BIM を用いたシミュレーションとの連携が想定される。このシ ミュレーションは BIM モデル上にそれぞれの居室の着点を設定し, 着点同士の最短距離を探索,測定し,動線量を算出するものである。

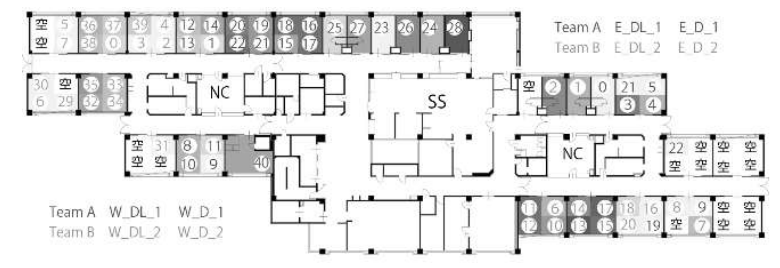

Fig. 4 Optimized Patient Placement of $\mathrm{H}_{-}$Hospital

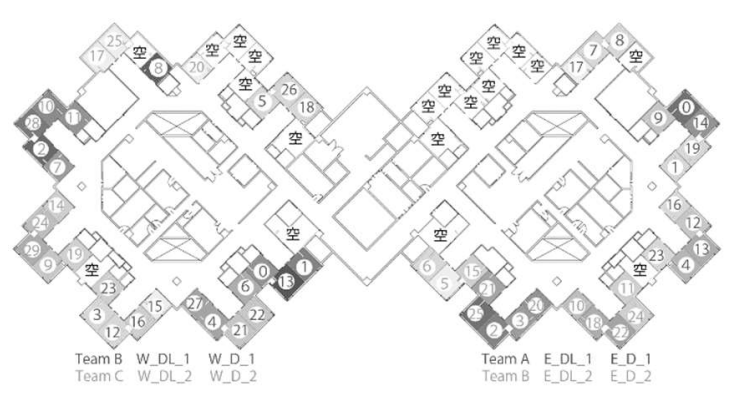

Fig. 5 Optimized Patient Placement of G_Hospital
Dynamo 上で本アルゴリズムを実行し,最適解の患者配置に従い設 定した着点を自動的に変更することで適用することができる。これ により,シミュレーションにシームレスにつなげることができる。

\section{5. 看護動線量シミュレーションによる分析}

ここから,BIM を用いた看護動線量シミュレーションを用い,看護 動線量の観点から, 病棟計画及び運営に関する分析・考察を行う。

\section{5-1アルゴリズムで得た患者配置}

Fig.4 に $\mathrm{H}$ 病院, Fig.5 に G 病院の各病棟における最適解として 得た患者配置を示し, Fig.6 $6 \mathrm{H}$ 病院, Fig. 7 に $\mathrm{G}$ 病院の各病棟にお ける不適解として得た患者配置を示す。また各患者の看護必要度を ヒートマップで示し,色が濃くなるほど高い看護必要度となる。

(1) 患者配置の最適解

$\mathrm{H}$ 病院では, $\mathrm{W}$ 病棟は個室病室に入室している患者が全て $\mathrm{A}$ チー ムの担当であり, SS からの距離よりも同チームでのまとまりが優先 され,Aチームが SS から近い病室, B チームが SS から遠い病室に配 置されたといえる。また $\mathrm{E}$ 病棟は B チームに看護必要度が高い患 者が多く,その患者が NC から近い病室に配置され,それを基準に他 の患者が配置されたと考えられる。 $\mathrm{H}$ 病院では,チームのまとまりと いう観点から現状も最適に近い配置がされたといえる。

$\mathrm{G}$ 病院では,両病棟ともにチームごとに集約された配置が得られ た。回廊型円形的病棟では, SS と病室の距離に大きく差がないため, 重症室に入室した患者を基準として患者が配置されたと考えられる。 (2) 患者配置の不適解

各病棟で患者配置における看護動線量を定量的に把握するために, 看護動線量の観点から最も不適であると想定される患者配置も得た。 GA の評価值が最大值を得るように最適化し, 不適解を得た。

$\mathrm{H}$ 病院では, 両病棟で基本的に看護必要度の高い患者が SS から遠 い病室に配置された。W 病棟ではチームでまとめる必要がないため, チームにもばらつきが見られ,看護必要度が優先されたと考えられ る。 $\mathrm{E}$ 病棟では $\mathrm{NC}$ からやや遠い病室に空ベッドが見られる。B 一ムの看護必要度の高い患者が遠い病室に配置されたため, 受け持 ち患者を離すことが優先されたものだと考えられる。

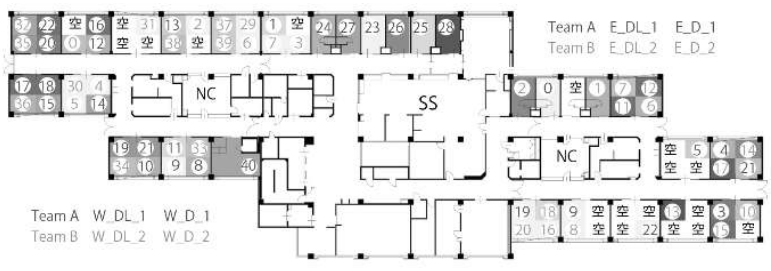

Fig. 6 Inappropriate Patient Placement of H_Hospital

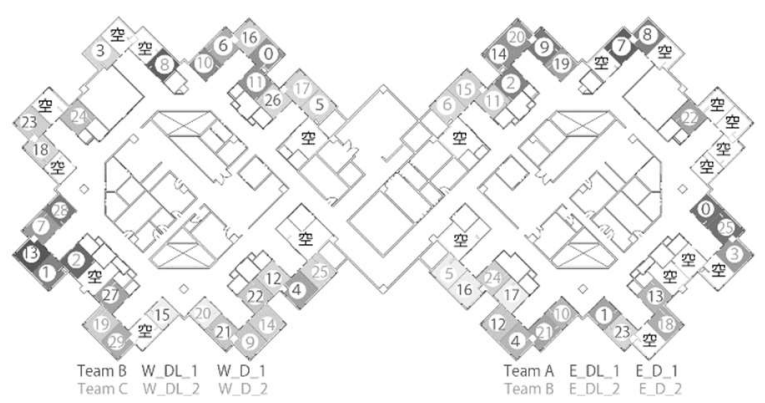

Fig. 7 Inappropriate Patient Placement of G_Hospital 
$\mathrm{G}$ 病院では,両病棟ともにチームにばらつきが見られ, 看護必要度 の高い患者が, SS から遠い病室に配置された。

\section{5-2＼cjkstart最適解の患者配置によるシミュレーション分析}

Table 4 中 B 行に最適配置でのシミュレーション結果を示す。

$\mathrm{H}$ 病院の結果を見ると,ほとんどの看護師で看護動線量が削減さ れた。病棟内の対象看護師全体では, $\mathrm{W}$ 病棟で $9.9 \%, \mathrm{E}$ 病棟で $13.2 \%$ 削減され,全ての看護師で増減率がかなり高いことがわかる。現状の 配置は,チームのまとまりとしては最適に近い状態であったが, 看護 必要度による配置の最適化により大きく看護動線量が削減された。 比較的増減率が低い E_DL_1 と E_DL_2 については病室訪問回数 が多いことと,担当外患者への訪問割合が高い点が共通している。

一方で,W_DL_2では看護動線量が削減されず,わずかに増加して いる。この看護師は患者訪問回数と担当外患者への訪問割合が非常 に高かった。このように病室訪問回数と担当外患者への訪問割合が 増減率に大きく影響を与えていると考えられる。

$\mathrm{G}$ 病院の結果を見ると,ここでもほとんどの看護師で看護動線量 が削減される結果となった。削減された看護師の増減率をみると W_D_2 を除き病室訪問回数が多いほど,増減率が高くなる傾向があ る。回廊型の円形的病棟では SS-病室間の距離の差が大きくないた め, 病室間の移動距離が最適化により短縮されたことによるものだ と考えられる。E_DL_2 は看護動線量が削減されているものの訪問 回数に対して増減率は高くない。最適化した患者配置では看護動線 が多く訪問している病室に集中しており,各病室もまとめて配置さ れている。しかし, 現状の配置の場合も SS から近い病室に看護動線 が集中しており, 病室間の移動より SS から病室への移動が多かった 可能性を含めると, 現状で既にかなり効率的な看護師の移動が行わ れていたと推測される。

一方で，W_D_2では看護動線量が大きく増加している。この看護 師は病室訪問回数が非常に少ない点が特徴として挙げられる。同ユ ニットに配置されていた患者同士の訪問が多かったにもかかわらず， 配置変更によりその患者同士が離れてしまうなどの影響を受けやす くなっていると考えられる。病棟内の対象看護師全体では, 5.3\%削 減されているため,病棟全体で見れば最適化されている。また $\mathrm{E}$ 病
棟では全体で $6.9 \%$ 削減され,両病棟ともに, $\mathrm{H}$ 病院程の看護動線量 の削減は見られなかった。SS-病室間の距離に差のない回廊型円形 的病棟であることが影響していると考えられる。

\section{5-3＼cjkstart不適解の患者配置によるシミュレーション分析}

Table 4 中 C 行に不適配置でのシミュレーション結果を示す。

$\mathrm{H}$ 病院の結果では,分散型看護拠点が活用されていないため,全て の看護師で看護動線量が増加する結果となった。病棟内の対象看護 師全体では, $\mathrm{W}$ 病棟で $14.7 \%, \mathrm{E}$ 病棟で $19.9 \%$ 増加し,全ての看護師 でかなり高い。W_DL_1 及び E_DL_2 は非常に増加率が高くなって おり,訪問回数が多いことと担当患者を中心に訪問していることが 共通している。W_DL_2 及びW_D_2 は比較的増加率が低い。これ は,担当外の患者への訪問割合が非常に多いこと, SS に近い病室に 担当患者が多く配置されたことによるものだと考えられる。 E_DL_1は同様に,担当外の患者一の訪問割合が多いが,増加率はそ れほど少なくない。これは, 担当外の患者と比較すると担当患者が $\mathrm{NC}$ から遠い病室に配置されたことによるものと考えられる。

病棟内の対象看護師全体の最適解との差は, $\mathrm{W}$ 病棟が $24.6 \%, \mathrm{E}$ 病 棟が $33.1 \%$ となり $\mathrm{E}$ 病棟に非常に大きな差が生まれた。 $\mathrm{E}$ 病棟は空 きベッドが非常に多く,単に空きベッドを遠くもしくは近くの病室 に配置するだけの最適・不適解が生まれるため,増減率に差が生まれ たと考えられる。実際の看護業務での利用も考慮した空きベッドの 配置についてアルゴリズムに組み込むことで,より実務に近い最適・ 不適解を得ることができると考えられる。

$\mathrm{G}$ 病院の結果を見ると,ここでも全ての看護師で看護動線量が増 加する結果となった。病棟内の対象看護師全体では,W 病棟で $10.4 \%$, $\mathrm{E}$ 病棟で $13.9 \%$ 増加し,全ての看護師でかなり高いが,不適解でも $\mathrm{H}$ 病院程は増加しなかった。E病棟において E_DL_2 は増加率が高く, 前述のように現状で既に効率的な看護師の移動が行われたと考える とそれにより看護効率が非常に悪くなったと推察される。

病棟内の対象看護師全体の最適解との差は, $\mathrm{W}$ 病棟が $15.7 \%, \mathrm{E}$ 病 棟が $20.8 \%$ となった。最適解との差でも $\mathrm{H}$ 病院程大きくない。ここ からも, SS-病室間の距離に差のない回廊型円形的病棟では比較的, 患者配置により看護動線量に差が出にくいことが検証された。

Table 4 Simulation Results

\begin{tabular}{|c|c|c|c|c|c|c|c|c|c|c|c|c|c|c|c|c|c|c|c|c|c|c|}
\hline & & \multirow{4}{*}{$\begin{array}{l}\text { Team } \\
\text { Nurse } \\
\end{array}$} & \multicolumn{10}{|c|}{ H_Hospital } & \multicolumn{10}{|c|}{ G_Hospital } \\
\hline & & & \multicolumn{5}{|c|}{ W_Hospital Ward } & \multicolumn{5}{|c|}{ E_Hospital Ward } & \multicolumn{5}{|c|}{ W_Hospital Ward } & \multicolumn{5}{|c|}{ E_Hospital Ward } \\
\hline & & & \multicolumn{2}{|c|}{$\mathrm{A}$} & \multicolumn{2}{|c|}{$B$} & \multirow{2}{*}{ Total } & \multicolumn{2}{|c|}{ A } & \multicolumn{2}{|c|}{ B } & \multirow{2}{*}{ Total } & \multicolumn{2}{|c|}{$B$} & \multicolumn{2}{|c|}{$\mathrm{C}$} & \multirow{2}{*}{ Cotal } & \multicolumn{2}{|c|}{ A } & \multicolumn{2}{|c|}{ B } & \multirow{2}{*}{ Total } \\
\hline & & & w_DL_1 & W_D_1 & W_DL_2 & W_D_2 & & E_DL_1 & E_D_1 & E_DL_2 & E_D_2 & & W_DL_1 & W_D_1 & W_DL_2 & W_D_2 & & E_DL_1 & E_D_1 & E_DL_2 & E_D_2 & \\
\hline & \multirow{3}{*}{$\begin{array}{c}\text { Present } \\
\text { Situation }\end{array}$} & Travel Time (min.) & 64.7 & 40.8 & 98.3 & 51.2 & 255.0 & 67.3 & 27.8 & 56.1 & 32.5 & 183.7 & 80.6 & 33.9 & 63.9 & 39.3 & 217.7 & 58.1 & 53.3 & 82.6 & 48.2 & 242.2 \\
\hline & & Travel Distance $(\mathrm{m})$ & 4853 & 3058 & 7371 & 3842 & 19123 & 5049 & 2086 & 4209 & 2435 & 13780 & 6046 & 2546 & 4796 & 2949 & 16337 & 4358 & 3996 & 6195 & 3611 & 18160 \\
\hline & & \begin{tabular}{|c|} 
Number of Visits to \\
Patient Room (times) \\
\end{tabular} & 124 & 73 & 201 & 68 & 466 & 133 & 58 & 1 & 81 & 15 & 90 & 36 & 47 & 28 & 201 & 73 & 51 & 121 & 57 & 302 \\
\hline \multirow{5}{*}{ 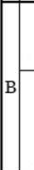 } & Optimized & Travel Time (min.) & 54.2 & 34.1 & 100.2 & 41.2 & 229.7 & 58.9 & 23.7 & 49.9 & 27.0 & 159.5 & 69.6 & 32.7 & 60.6 & 43.3 & 206.2 & 51.2 & 51.0 & 78.0 & 45.2 & 225.4 \\
\hline & & Travel Distance $(\mathrm{m})$ & 4067 & 2560 & 7517 & 3090 & 17232 & 4419 & 1778 & 3741 & 2028 & 11966 & 5216 & 2452 & 4545 & 3250 & 15464 & 3841 & 3827 & 5847 & 3391 & 16907 \\
\hline & \multirow{3}{*}{$\begin{array}{l}\text { Comparison } \\
\text { with A }\end{array}$} & Reduced Time (min.) & -10.5 & -6.7 & 1.9 & -10.0 & -25.3 & -8.4 & -4.1 & -6.2 & -5.5 & -24.2 & -11.0 & -1.2 & -3.3 & 4.0 & -11.5 & -6.9 & -2.3 & -4.6 & -3.0 & -16.8 \\
\hline & & Reduced Difference (m) & -786 & -498 & 146 & -752 & -1890 & -630 & -308 & -468 & -407 & -1814 & -830 & -94 & -251 & 301 & -873 & -516 & -169 & -347 & -221 & -1253 \\
\hline & & Reduced Rate (\%) & -16.2 & -16.4 & 1.9 & -19.5 & -9.9 & -12.5 & -14.7 & -11.1 & \begin{tabular}{|l|}
-16.9 \\
\end{tabular} & -13.2 & -13.6 & -3.5 & -5.2 & 10.2 & -5.3 & \begin{tabular}{|l|}
-11.9 \\
\end{tabular} & -4.3 & -5.6 & -6.2 & -6.9 \\
\hline \multirow{2}{*}{\multicolumn{2}{|c|}{$\begin{array}{c}\text { Inappropriate } \\
\text { Patient } \\
\text { Placement } \\
\end{array}$}} & Travel Time (min.) & 84.6 & 45.7 & 106.6 & 55.5 & 292.4 & 76.1 & 31.8 & 72.9 & 39.4 & 220.2 & 86.0 & 41.6 & 68.2 & 44.5 & 240.3 & 65.7 & 58.9 & 100.6 & 50.6 & 275.8 \\
\hline & & Travel Distance (m) & 6345 & 3430 & 7992 & 3517 & 21283 & 5711 & 2388 & 5466 & 2956 & 16521 & 6451 & 3122 & 5118 & 3339 & 18031 & 4928 & 4419 & 7545 & 3798 & 20690 \\
\hline & \multirow{3}{*}{$\begin{array}{l}\text { Comparison } \\
\text { with A }\end{array}$} & Reduced Time (min.) & 19.9 & 4.9 & 8.3 & 4.3 & 37.4 & 8.8 & 4.0 & 16.8 & 6.9 & 36.5 & 5.4 & 7.7 & 4.3 & 5.2 & 22.6 & 7.6 & 5.6 & 18.0 & 2.4 & 33.6 \\
\hline & & Reduced Difference $(\mathrm{m})$ & 1493 & 372 & 621 & 323 & 2161 & 662 & 302 & 1256 & 323 & 2741 & 405 & 576 & 322 & 323 & 1694 & 570 & 423 & 1351 & 323 & 2531 \\
\hline & & Reduced Rate (\%) & 30.8 & 12.0 & 8.4 & 8.4 & 14.7 & 13.1 & 14.4 & 29.9 & 21.2 & 19.9 & 6.7 & 22.7 & 6.7 & 13.2 & 10.4 & 13.1 & 10.5 & 21.8 & 5.0 & 13.9 \\
\hline \multirow{2}{*}{\multicolumn{2}{|c|}{$\begin{array}{c}\text { Optimized Placement } \\
\text { without Travel } \\
\text { Frequency }\end{array}$}} & Travel Time (min.) & 59.6 & 34.9 & 94.2 & 43.5 & 232.2 & 58.5 & 22.5 & 51.6 & 27.4 & 160.0 & 77.2 & 37.0 & 63.2 & 41.1 & 218.5 & 61.3 & 50.6 & 100.1 & 55.4 & 267.4 \\
\hline & & Travel Distance (m) & 4474 & 2617 & 7063 & 3266 & 17419 & 4390 & 1688 & 3870 & 2052 & 11999 & 5790 & 2772 & 4743 & 3085 & 16390 & 4595 & 3798 & 7509 & 4152 & 20053 \\
\hline & & Reduced Time (min.) & -5.1 & \begin{tabular}{|l|}
-5.9 \\
\end{tabular} & -4.1 & \begin{tabular}{|l|}
-7.7 \\
\end{tabular} & -22.8 & -8.8 & -5.3 & -4.5 & -5.1 & -23.7 & -3.4 & 3.1 & -0.7 & 1.8 & 0.8 & 3.2 & -2.7 & 17.5 & 7.2 & 25.2 \\
\hline & $\begin{array}{l}\text { Comparison } \\
\text { with } \mathrm{A}\end{array}$ & Reduced Difference $(\mathrm{m})$ & -379 & -441 & -308 & -576 & -1704 & -659 & -398 & -340 & -384 & -1780 & -256 & 226 & -53 & 136 & 53 & 237 & -199 & 1314 & 541 & 1893 \\
\hline & & Reduced Rate (\%) & -7.9 & -14.5 & -4.2 & -15.0 & -8.9 & $|-13.1|$ & -19.1 & -8.0 & -15.7 & -12.9 & -4.2 & 9.1 & -1.1 & 4.6 & 0.4 & 5.5 & -5.1 & 21.2 & 14.9 & 10.4 \\
\hline
\end{tabular}




\section{5-4＼cjkstart移動頻度を考慮しない患者配置による分析}

本研究で行った最適化方法は,SS からの距離・病室間の距離・看 護必要度の高低・看護師の移動頻度を考慮し最適化するものである。 両病院で患者配置を変更したシミュレーションから, 担当外の病室 や空病室への移動がある場合, 看護動線量が増える可能性あること が確認された。 $\mathrm{H}$ 病院では $\mathrm{E}$ 病棟の $\mathrm{A}$ チームの看護師以外, $\mathrm{G}$ 病院 では全ての看護師で担当外の病室や空病室への移動が発生していた。 次に,看護師の移動頻度(相互関係行列)を考慮せずに最適化した場合 の患者配置に変更した,シミュレーションをみる。(Table 4 中 D 行)。 各病院の増減率は, 病棟内の対象看護師全体で, $\mathrm{H}$ 病院の $\mathrm{W}$ 病棟が$8.9 \%, \mathrm{E}$ 病棟が $-12.9 \%, \mathrm{G}$ 病院の $\mathrm{W}$ 病棟が $+0.4 \%, \mathrm{E}$ 病棟が $+10.4 \%$ となり,両病院で最適解の配置と比較すると増減率が増加した。 $\mathrm{H}$ 病 院のような看護拠点から病室の距離に差がある場合や担当外の病室 への移動が多い場合でも, 本研究での最適化が看護動線の観点から の有効性を確認できた。また G 病院のような SSを中心とした回廊 型円形的病棟でも,本研究での最適化が看護動線の観点からの有効 性を確認できた。この患者配置では両病院の看護動線量の増減率に 大きな違いが生まれた。 $\mathrm{H}$ 病院では最適解と比較して看護動線量が 増加したがあまり差がない。担当患者のみを訪問した W_DL_1 や W_D_1 も看護動線量は削減されており,チームのまとまりを考慮し た患者配置では看護効率は大きく上昇しないことが分かった。 $\mathrm{G}$ 病 院では, 看護動線量が現状と比較して増加しており, $\mathrm{E}$ 病棟では特に 顕著だった。G 病院の病棟平面では, 対角に設置された病室に移動す る際の距離が非常に長く,病室間の移動を短縮できるチームのまと まりを考慮した患者配置で看護効率が上昇寸ることが分かった。

\section{6. まとめ}

病室間の距離・看護師チームの受け持ち患者から仮定した移動頻 度・ SS一病室間の距離・患者の看護必要度を評価值として患者配置 の最適解・不適解など様々な患者配置について, GA を用いることで シミュレーションを行い得た。SS-病室間の距離に差のない回廊型 円形的病棟と,差がある分散型看護拠点未利用の病棟平面と比較し て,患者配置の最適・不適により看護動線量に差があることを示寸こ とができ,チームのまとまりを考慮した患者配置において, 看護効率 に与える影響を考察することができた。病棟部の平面型と患者配置 の運営型の対応関係から, BIM シミュレーションを用い,計画設計の 初期段階から検討できる可能性を示すことができた。

今後, 多様な病棟平面型と運営型との多義的な対応関係, また GA を用いたアルゴリズム進化過程から，BIM シミュレーションの精度 を高め,計画設計の初期段階から病棟平面を検討する計画設計プロ セスや,より汎用性が高い看護動線モデルの開発を進めていきたい。

\section{参考文献}

1) Taniguchi, G., Yanagisawa, M., Imai, S., Kato, A., Yamamoto, K. and Shida, K.: A Study on Nursing Activities in Hospital Ward, Transactions of the Architectural Institute of Japan, No. 344, pp.116125, 1984. 10 (in Japanese)

谷口元, 柳澤忠, 今井正次, 加藤彰一, 山本和典, 志田弘二: 看護動線 量の予測に関する基礎的研究, $\mathrm{N}$ 病院外科系病棟への適用，日本建築 学会論文報告集, 344 巻, pp. 116-125, 1984. 10

2) Toriyama, A., Watanabe, R., Nakayama, S., Kakehi, A. and Yamashita, T.: Research on Function and Location of "Personal
Nursing Bases" And Other Types of Nursing Bases, Reexamination, studies on planning of acute care wards in the era of computerization of medical and patients' information Part II, Journal of Architecture and Planning (Transactions of AIJ), Vol. 73, No. 625, pp.527-533, 2008. 3 (in Japanese)

鳥山亜紀，渡辺玲奈，中山茂樹，筧淳夫，山下哲郎：「パーソナル看護拠 点」およびその他の看護拠点の機能と配置に関する研究一医療・患者情 報の電子化と急性期病棟計画の再検討 その 2 - , 日本建築学会計画系 論文集, 73 巻, 625 号, pp. 527-533, 2008.3

3) Hendrich, A., Chow, M., Bafna, S., Choudhary, R., Heo, Y., \& Skierczynski, B. A.: Unit-related factors that affect nursing time with patients, Health Environments Research \& Design Journal, Vol.2, No.2, Winter, pp.5-20, 2009

4) Takeuchi, T., Yamaguchi, K., Takagi, M. and Kato, A.: Study on Evaluation for Hospital Ward Planning and Management by Nursing Travel Distance Simulation using BIM, Journal of Architecture and Planning (Transactions of AIJ), Vol. 85, No. 767, pp.33-40, 2020. 1 (in Japanese)

竹内貴洋, 山口恭平, 高木碧, 加藤彰一: BIM を用いた看護動線量シミ ユレーションによる病棟計画及び運営の評価に関する研究, 日本建築 学会計画系論文集, 85 巻, 767 号, pp.33-40,2020. 1

5) Watanabe, R., Toriyama, A., Nakayama, S.: A Basic Study on Nursing Care Needs of Perioperative Period in Acute Care Wards, Studies on reconstruction of acute care wards from the nursing care view, Journal of Architecture and Planning (Transactions of AIJ), Vol. 76, No. 666, pp.1371-1378, 2011. 8 (in Japanese)

渡辺玲奈，鳥山亜紀，中山茂樹：急性期病棟における周手術期および看 護師の訪問回数と看護必要度との関連一看護ケアから検討する急性期 病棟計画の再構築一, 日本建築学会計画系論文集, 76 巻, 666 号, pp.1371-1378, 2011. 8

6) Ohkita, M., Kawabata, H., Ohshima, M., Tachibana, S., Ohshima, A., Ohhira, M.; Actual Situation of Pairing Rate and Movement Distance in Daily Duties under Partnership Nursing System, Proceedings of Japan Association for Medical Informatics Nursing Informatics Conference, pp.118-121, 2014.8 (in Japanese)

大北美恵子，川端宏枝，大島未喜，橘幸子，大島暁，大平雅雄 : パートナ ーシップ・ナーシング・システムによる日常業務のペア率と移動距離の 実態，日本医療情報学会看護学術大会論文集, pp.118-121, 2014.8

7) Suzuki, A., Considerations of GA Solving Method using Block Crossover for Two-dimensional Layout Problem, Departmental Bulletin Paper Informatics Research, No.6, pp.5-13, 2017-02 (in Japanese)

鈴木 淳，二次元配置問題のためのブロック交叉を用いた GA 解法に関 する考察, 情報学研究, No.6, pp.5-13, 2017-02, 獨協大学学術リポジト リ http://id.nii.ac.jp/1140/00000979/ (last accessed 2021.1.28)

注

注1） $\mathrm{H}$ 病院の調査は，この他に遅出看護師 1 名，夜勤看護師 2 名に対して も行われたが, $\mathrm{G}$ 病院の調査との差を加味し, 本研究では日勤を中心 に分析することとした。

注2）看護必要度は，主にモニタリング及び処置の度合いを測る $\mathrm{A}$ 項目と寝 返り等が可能かといった患者の状態を評価する B 項目, 手術等の医学 的状況を評価する $\mathrm{C}$ 項目からなる。

注3）福井大学医学部付属病院の PNS の定義「2 人の看護師が安全で質の 高い看護を共に提供することを目的に，良きパートナーとして対等な 立場で互いの特性を活かし, 相互に補完し協力し合って, 毎日の看護 ケアをはじめ委員会活動・病棟内の係の仕事に至るまで 1 年を通じて 活動し，その成果と責任を共有する看護体制」。

注4) $\mathrm{H}$ 病院の調査では患者のプライバシーの観点から病室内の追跡は行っ ておらず，4 床室では看護師の患者ごと訪問回数について把握できて いない。そのため, 病室訪問回数と病室内患者の看護必要度の比例関 係を用い，病室訪問回数から患者の訪問回数を概算して用いている。 担当・担当外への移動回数の分析においては, 現状もチームごとにま とまった配置とされていたため, ほぼ正確な值で示されている。

注5） 本プログラムは、ネット上の技術情報共有サービスを参照して作成し たもので、大域探索手法の確立や進化的戦略の導入など改善点は多い。 


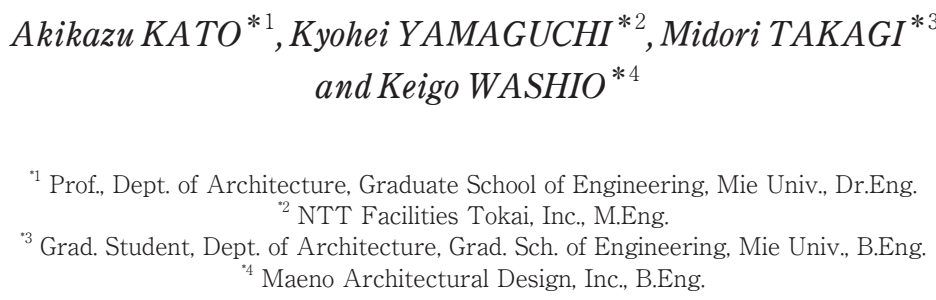

This study aims to develop the Building Information Modeling, BIM, system that enables simulations based on multiple fit between variety of floor plan types and management types in the facility planning, programming, design, and management of hospital wards. In this paper floor plan types of a dispersed nursing base type and a circular corridor type were focused and management types regarding patient placement and nursing travel distance were considered.

The case of the dispersed nursing base floor type consisted of four bed rooms and single bed room, which is still quite common in Japan, whereas the circular corridor floor plan type used only single bed rooms, which is still unique. When patient bed rooms are placed along the corridor, the placement of four single rooms requires the double corridor length compared to the placement of one four bed room. Thus, a unit hall scheme was introduced in the case studied ward floor plan where five single rooms share same unit hall functioning as a one five bed room as a whole.

The management research topic included the differences in the nursing system, patient duty allocation, teaming concept, etc. The paper also refers to the topic of Partnership Nursing System, PNS, in which a pair of two nurses conducts the duty as an equal partner. The analysis looked into the level of equality from the movement distances of two nurses.

The nursing travel survey was conducted in four wards of two hospitals to investigate the relationship between nursing activities and the number of visits to patient rooms. The conventional time study method was used where an investigator followed each nurse to record time, from and to locations, tasks, and goods carried. The factors influencing nursing travel distance and patient placements were analyzed including the nursing necessity index based on seriousness of patients' illness.

The simulations were carried out to make predictions with optimal and inappropriate versions of patient placements using genetic algorithm, GA. The program was written using Python 3.7 applied on Autodesk Revit as BIM system through Dynamo as Visual Programming Language, VPL.

As the result of these simulations, various fit between the floor type and management type were clarified including the phenomenon that the difference in calculated nursing travel distance was small in the circular corridor floor plan type because the distance between the staff station and patient bed rooms was small under different conditions of patient placements. Also, the equality in PNS was confirmed. 